\title{
From cult to community: The two halves of Leviticus
}

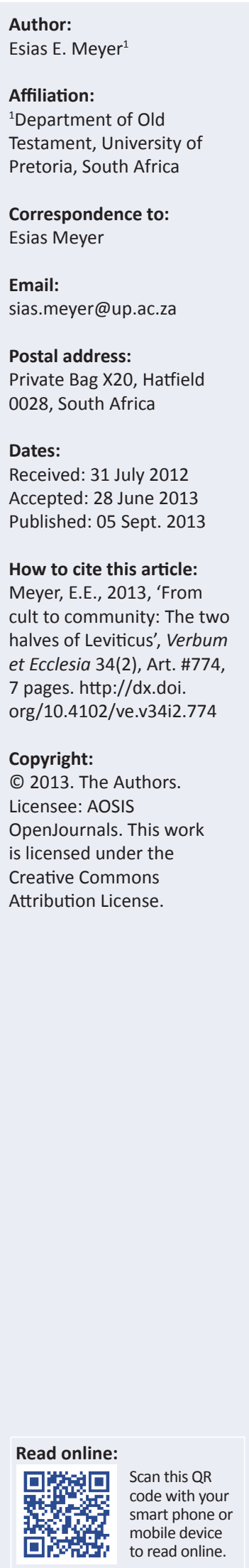

Traditionally in Old Testament redactional criticism, a distinction is made between the first half of Leviticus (usually Lv 1-16) and the second half (Lv 17-26). In historical-critical jargon, the first half is usually regarded as part of the Priestly texts $(\mathrm{P})$ and the second is called $\mathrm{H}$ by some, after the Holiness Code. Some have argued that Leviticus 1-16 is mostly concerned with what we would call rituals, whereas the second half (or H) is concerned with 'ethics', amongst other things. The article attempted to explore the relation between rituals and ethics by first asking what Old Testament critics seem to mean when they use terms such as 'ritual' and 'ethics'. The article then critically engaged with two different hypotheses which attempt to explain the ethical turn in the Book of Leviticus.

\section{Introduction}

This article will address a rather old question in the interpretation history of Leviticus. Why are there texts in the second half of the Book of Leviticus which address different issues from what we find in the first half? The difference in the second half is that certain ethical and moral issues are suddenly addressed, issues which have not been raised in Leviticus 1-16. In the days of Wellhausen, it was argued that the Holiness Code (H) (i.e. Lv 17-26) was an older collection which had, at some stage, been incorporated into Leviticus, or in Wellhausen's terms added to the 'Priestercodex'. ${ }^{1}$ In this scheme of things, the moral issues addressed reflected something of an older religion still closely connected to agriculture (Trevaskis 2011:4).

Things have radically changed in the last few decades, with more and more scholars agreeing that $\mathrm{H}$ was created later than Leviticus 1-16. There are two groups of scholars who support this view. On the one hand, there are (mostly) Jewish scholars who belong to what one could call the 'Kaufmann School', ${ }^{2}$ of which Jacob Milgrom and Israel Knohl would probably be the foremost examples. For both Milgrom and Knohl, H was produced by a Holiness School that consisted of priests, but who belonged to a later generation than those who produced the bulk of the earlier Priestly source (P), of which Leviticus 1-16 forms part. In Europe, similar arguments are followed by scholars belonging to the 'redactional critical' (as described by Stackert 2009:195) school, of which Eckart Otto, Reinhard Achenbach and Christophe Nihan would probably be the best examples. These two groups differ on the dating of these texts, but they agree on the chronological relationship between $\mathrm{P}$ and $\mathrm{H}$. For all of them, $\mathrm{H}$ was written after $\mathrm{P}$.

One of the arguments (especially used by Milgrom ${ }^{3}$ and $\mathrm{Knohl}^{4}$ ) to argue for the distinction between $\mathrm{H}$ and $\mathrm{P}$ is the fact that, whereas $\mathrm{P}$ is focused on the cult itself and the rituals aimed at maintaining the cult, $\mathrm{H}$ broadens its horizons to include what we might call 'ethics'. Bibb (2009:152) puts this as follows: 'The central movement [from $P$ to $H$ ] ... is the shift from a narrow cultic focus to the larger communal setting.' What is meant by a 'narrow cultic focus' and a 'larger communal setting'? Or what is meant when one describes this as a move from 'rituals ${ }^{\prime 5}$ to 'ethics'? The answer to these questions is fairly simple and a quick overview of the content of the Book of Leviticus should make this clear.

1.See Wellhausen's comment in Jüngling (1999:29) or Otto (1999:132)

2.By the 'Kaufmann School', I refer to scholars who argue that the Priestly texts are pre-exilic. See Meyer (2010) for an overview and critical discussion, or especially the debate between Milgrom (1999) and Blenkinsopp (1996).

3.See Milgrom (2004:215-219). Milgrom's heading for this discussion is ' $\mathrm{H}$ and ethics'. For Milgrom (2004:215), the 'bonding of ethics and ritual' is not unique to Israel, but is often found in Mesopotamia and even Egypt. What one finds in the Holiness Code (H) though 'is the subsumption of rituals and ethics under the rubric of holiness' (italics in original). This combination is only found in Israel and, specifically, in $\mathrm{H}$.

4.See Knohl (1995:175-180). Knohl's heading is 'morality and the cult' and he basically refers to all the examples used by Milgrom. For Knohl, 'morality' thus becomes a synonym for Milgrom's 'ethics'.

5.The term 'ritual' is, of course, a highly problematic term and notoriously difficult to define. Some biblical critics, such as Wright (2001:13) and Bibb (2009:53), would follow Catherine Bell (1992) in her use of the broader concept of ritualisation. For Wright (2001:13), the 'contrast between ritualization and normal activity' becomes important in this approach. I will not venture into this debate here, but rather focus on the content of the two halves of Leviticus and the problem of relating the two to each other. 
Most of the laws in Leviticus 1-16 are concerned with the cult and maintaining the cult. Leviticus 1-7 is about different kinds of offerings, which include the burnt offering (chapter 1), the grain offering (chapter 2), the offering of well-being (chapter 3), the purification offering (chapters 4 and 5), the reparation offering (chapter 5) and some more general instructions on sacrifices (chapters 6 and 7). The Hebrew root $k p r$ occurs regularly ${ }^{6}$ in these chapters, except for chapters 2 and 3 . The root $k p r$ is often translated as 'to make atonement' and, in most of the instances in Leviticus 1-7, it is the priest who makes atonement on behalf of the person who has brought the offering. The verb does not occur in chapters 2 and 3 because the purpose of the grain offerings and offering of well-being is not atonement. Leviticus 1-7 is followed by the first narrative in the Book of Leviticus in chapters 8-10. Chapters 8 and 9 describe how Aaron and his sons are ordained and the end result is a cultic climax at the end of Leviticus 9, when the glory of the Lord appears to all the people (v. 23) and eventually fire comes from the Lord and consumes the burnt offering and the fat on the altar. The people are in awe, but then, in Leviticus 10, things take a turn for the worse, when the sons of Aaron die because they did something wrong. Bibb (2009:111) has described the events in this narrative as a case of 'ritual failure'.?

Leviticus 11-15 is concerned with clean and unclean animals (chapter 11), female purification after child birth (chapter 12) and then three chapters (13-15) on 'leprosy's and bodily fluids. Chapter 11 is concerned with correct eating, whereas chapters $12-15$ tend to describe the procedures to be followed by somebody who has become unclean because of the conditions described and wants to become clean again. Leviticus 16 is about the Day of Atonement and it also describes sacrifices made to bring about reconciliation between $\mathrm{YHWH}$ and his people. The root $k p r$ also dominates this chapter. ${ }^{9}$ These texts thus clearly focus on the cult and could be described, as Bibb (2009) did, as having a 'narrow cultic focus'.

In the second half of Leviticus, there is a movement away from this 'narrow cultic focus' to broader issues. This movement is not really evident in Leviticus 17, which is usually regarded as the first chapter of the Holiness Code. Chapter 17 forbids profane slaughter and the eating of blood. This chapter is often regarded as a kind of hinge between the preceding half of Leviticus and the subsequent Holiness Code (see Meyer 2012). One community-related concern which now comes to the fore is the relation between the Israelite and the stranger $(g \bar{e} r)$. Strangers are also forbidden to carry out profane slaughter and they may not consume blood either. The strangers actually appeared for the first time in the previous chapter ( $\mathrm{Lv} 16)$, where they are also forbidden to work on

6.See Leviticus $1: 4 ; 4: 20,26,31,35 ; 5: 6,10,13,16,18,26 ; 6: 23 ; 7: 7$.

7.See also Bibb (2009:111-132) for a more detailed engagement with Leviticus 10:1-7.

8.This term is traditionally used, but it does not refer to Hansen's disease. When found on a human being, it is more of a kind of skin disease and it can even be found in houses when it becomes a kind of mould.

9. See verses $6,10,11,16,17(\times 2), 18,20,24,27,30,32,33(\times 2), 34$ the 7th day of the 10th month. In the rest of the Holiness Code, we find a clear communal focus in some texts, such as especially Leviticus $18-20$ and also in chapter 25 . Chapters 18 and 20 are concerned with sexual taboos, but especially in an extended family context, whereas chapter 19 is a strange mix of various kinds of legal texts, some reminiscent of the more cultic texts in the first half of Leviticus interested in both sacrifices and purity issues, whilst others remind us of the Decalogue and still others have been described as promoting 'social justice'. ${ }^{10}$

It is especially the latter two categories, namely texts reminding us of the Decalogue and texts that are concerned with 'social justice', which are described as more 'ethical'. ${ }^{11}$ Balentine (1999:169) describes the laws of Leviticus 19 as 'social ethics'. Decalogue-like texts include Leviticus 19:3, $4,11,12,16,18$ and $29 .{ }^{12}$ Texts that are often described as addressing issues of 'social justice' include especially verses 11-18 in which one finds commandments against keeping the day labourer's wages until morning, or putting a stumbling block in the way of a blind person, cursing the deaf and being partial in judgement. These laws are aimed at protecting the vulnerable in society, the kind of thing one finds in some of the Latter Prophets. One also finds laws protecting your neighbour from slander and from being hated by the addressees, but instead addressees are commanded to love (vv. 17-18) their neighbours as themselves, an injunction made famous by Jesus. Similar commands are again found in verses 33-34, which forbid the addressees to oppress the stranger and, once again, the addressees are asked to love the stranger as themselves.

This is what Bibb and others are referring to, namely the fact that the first half of Leviticus focuses on the cult and in the second half of Leviticus the focus is indeed wider and includes texts discussing the relationship between Israelites and their fellow Israelites as well their relationship with strangers. One could describe this as a 'turn to the other' as long as one qualifies this as not meaning a 'turn away from the cult'. The sanctuary is still very much at the centre, but other broader perspectives are included. Collins (2004) puts it well:

The code does not lessen the importance of ritual and purity regulations, but it puts them in perspective by alternating them with ethical commandments. Holiness is not only a matter of being separated from the nations. It also requires ethical behavior toward one's fellow human beings. (p. 151)

I will illustrate this point further by looking at the concept of holiness, as mentioned by Collins here, a concept found in both Leviticus 1-16 (P) and Leviticus 17-26 (H).

10.See, for instance, Nihan (2007:461), who argues that verses 11-18 have 'a strong thematic unity, since all the prohibitions deal in one sense or another with the issue of social justice'.

11.This article does not pretend to offer new insights on how to define the concept of 'ethics'. It does seem that biblical critics tend to use the term rather loosely. What should be clear though is that in discussions about $\mathrm{H}$ 'ethics' usually refers to texts which have a broader concern for the welfare of the community.

12.This list is from Balentine (1999:169, n. 78), who took it from Kaiser. I am not sure that verses 18 and 29 go back to the Decalogue. Mathys (1986:73-77) provides an overview of the debate until the 1980s. See also the summary in table format in Grünwaldt (1999:226-227). 


\section{Holiness}

Many scholars agree that the concept of holiness in the Holiness Code is somewhat different from what one finds in the first half of Leviticus. Scholars such as Milgrom (2004:175, 213-315) and Knohl (1995:180-186) have shown that holiness is a much broader term in $\mathrm{H}$ than it is in $\mathrm{P}$. But this argument goes back much further even to Wellhausen who, according to Trevaskis (2011:4), argued: 'Whereas H's concept of holiness embraced the people and the land, reflecting a pre-exilic agricultural setting, holiness in $\mathrm{P}$ had been abstracted from such matters.' Bibb (2009) describes the view of Wellhausen similarly as follows:

In the early stages, worship was spontaneous and uncontrolled by priestly hierarchy. This was the setting that saw the growth of the Holiness Code. During the Babylonian exile, the people had lost all connection with these popular forms of religion celebrating the land and agriculture. (p. 147)

As mentioned already, Wellhausen still held the view that $\mathrm{H}$ was older than $\mathrm{P}$ and that $\mathrm{P}$ eventually represented a step in the wrong direction, ${ }^{13}$ but today still few would dispute that the concept of holiness is broader in $\mathrm{H}$. By broader we mean that it includes the people of Israel, whereas in P it was mostly applied to the sanctuary, or to people and material associated with the sanctuary. Thus, in Leviticus 6:9-20, the grain offering is described as holy (adjective) and reserved only for the descendants of Aaron, who are to eat it in a holy place and anybody who touches it will become holy, presuming that this 'anybody' will be a priest. Or, in Leviticus 8, the verb ${ }^{14}$ occurs five times (vv. 10, 11, 12, 15 and 30) and in each case Moses is the subject of the verb and the object could be the tabernacle, its vessels, Aaron, the altar and the sons of Aaron. Later, in Leviticus 16:19, the altar is purified and sanctified. This is the only occurrence of the verb, but even when looking at the instances where the noun $(q \bar{o} \underline{d} \underline{e} \check{s})^{15}$

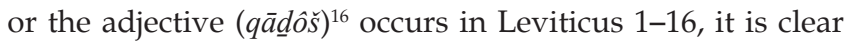
that it is only used with regard to the sanctuary, its officials and material associated with the sanctuary. The only exception here would be Leviticus 11:44-45, as illustrated in Table 1.

It is usually argued that these verses are not part of $\mathrm{P}$, but instead belong in H (see Milgrom 1991:691-698; Knohl 1995:105; Nihan 2007:298-299). In the text, it is clear that now both Yahweh ${ }^{17}$ and the people of Israel are regarded as holy. One finds that the addressees are the subject of the verb ( $q \underline{d} \check{s})$,

13.See Collins (2004:173), who argues that, for Wellhausen, the Priestly theology reflected the decline of Israelite religion, from the spiritual heights of the prophets to the legalism of "Late Judaism"'.

14.Apart from its occurrences in chapter 8 , the verb also occurs in $6: 11,20 ; 10: 3$ $11: 44 ; 16: 19 ; 20: 7,8 ; 21: 8,15,23 ; 22: 2,3,9,16,32 ; 25: 10 ; 27: 14,16,17,18,19$, 22,26 .

15.See Leviticus $2: 3,10 ; 4: 6 ; 5: 15,16 ; 6: 10,18,22,23 ; 7: 1,6 ; 8: 9 ; 10: 4,10,12,17,18$ $12: 4 ; 14: 13 ; 16: 2,3,4,16,17,20,23,27,32,33 ; 19: 8,24 ; 20: 3 ; 21: 6,22 ; 22: 2,3,4$, $6,7,10,12,14,15,16,32 ; 23: 3,4,7,8,20,21,24,27,35,36,37 ; 24: 9 ; 25: 12 ; 27: 3$, $9,10,14,23,25,28,30,32,33$

16.See Leviticus 6:9, 19, 20; 7:6; 10:13; 11:44, 45; 16:24; 19:2; 20:7, 26; 21:6, 7, 8 ; $24: 9$

17.Wright (1999:352) points out that in what he calls 'the Priestly Torah' we find only 'few, indirect words about God's holiness'. One such instance is Leviticus 10:3, bu some, such as Nihan (2007), would argue that this is the last chapter added to the book of Leviticus and thus later than both $\mathrm{P}$ and $\mathrm{H}$. which, in this case, is in the Hitpael and there are a few more nominal sentences ${ }^{18}$ in which either the addressees are asked to be holy or Yahweh is described as holy. It is clear that these two verses move away from a rather narrow cultic focus and this trend is continued in Leviticus 19:2 (see Table 2).

As in Leviticus 11:44-45, holiness becomes a quality not only reserved for the cult, its officials and material, but indeed the congregation of Israel and Yahweh. In the rest of the Holiness Code, one finds another two ${ }^{19}$ occurrences where the people are enjoined to be holy and this is usually expressed by means of an adjective used in conjunction with the root hyh. If one looks at the use of the verb, it seems that Israel itself, or obviously Yahweh, could be the subject of the verb, as Leviticus 20:7 illustrates (see Table 3).

In Leviticus 20:7, we find the root $q \underline{d} \breve{s}$ in the Hitpael (as in Lv 11:44) and in verse 8 it is a Piel participle. In verse 7, the addressees are the subjects and in verse 8 Yahweh is the subject, with the addressees becoming the object of the verb. Before these texts in Leviticus 19 and 20, the category of holiness has never been applied to the people in Leviticus, with the exception of the two verses from Leviticus 11. To put it simply, the Hebrew root for holiness is now applied not only to the cult, its officials and paraphernalia, but to ordinary people. Quite a few scholars have attempted to describe this expansion of the concept of holiness from $\mathrm{P}$ to H. Thus Wright (1999) says:

The Priestly Torah is more interested in priestly or cultic matters and only peripherally in how holiness relates to the cult. The Holiness School, in contrast, has holiness as its central focus and related it to God, humans, various places, objects, and time. (p. 352)

Similarly, Bibb (2009) has argued:

To be holy in $\mathrm{H}$ does not mean to be set apart for a specific use in the cultic sphere. Rather, it implies a total relation to the deity that includes but transcends the cultus and engages the people in their everyday lives. (p. 145)

Grünwaldt (1999:253) has pointed out that Leviticus 19:2 is the only place in the Old Testament where YHWH's holiness is used as motivation for ethical instructions. For Grünwaldt, this is not necessarily a case of the concept of holiness being ethisiert [ethicised], but rather a case of YHWH's holiness being extended to include Israel's everyday 'Lebenswirklichkeit'. It also means that no place is profane any longer, but everything becomes holy, which is similar to what Bibb argued above. It should thus be clear by now that the definition of 'holiness' is different in the second half of Leviticus than in the first half. The category of holiness is not only applied to the sanctuary, but to all of Israel and now includes what we would call ethical behaviour.

With regard to the abovementioned texts where the broader concept of holiness is found, it is important to take note of one last thing. All of these texts (excluding Lv 11:44-45) are usually regarded as part of the parenetic frame of the Holiness 18.For a definition of a nominal clause see Joüon and Muraoka (2006:528).

19.See Leviticus $20: 7,26$. There are, of course, other examples where the adjective is applied to the priests, such as Leviticus 21:6-8. 
TABLE 1: The original Hebrew text of Leviticus 11:44-45 and its English translation.

\begin{tabular}{|c|c|}
\hline BHS Leviticus 11:44-45 & NRSV Leviticus 11:44-45 \\
\hline 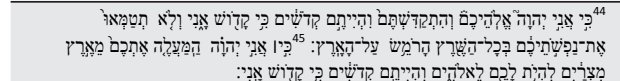 & $\begin{array}{l}{ }^{44} \text { For I am the Lord your God; sanctify yourselves therefore, and be holy, for I am holy. You shall not defile yourselves } \\
\text { with any swarming creature that moves on the earth. }{ }^{45} \text { For I am the Lord who brought you up from the land of Egypt, } \\
\text { to be your God; you shall be holy, for I am holy. }\end{array}$ \\
\hline
\end{tabular}

BHS, original Hebrew text; NRSV, New Revised Standard Version.

TABLE 2: The original Hebrew text of Leviticus 19:2 and its English translation.

\begin{tabular}{|c|c|}
\hline BHS Leviticus 19:2 & NRSV Leviticus 19:2 \\
\hline
\end{tabular}

BHS, original Hebrew text; NRSV, New Revised Standard Version.

TABLE 3: The original Hebrew text of Leviticus 20:7-8 and its English translation.

\begin{tabular}{|c|c|c|}
\hline BHS Leviticus 20:7-8 & & NRSV Leviticus 20:7-8 \\
\hline & 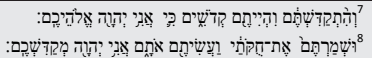 & $\begin{array}{l}{ }^{7} \text { Consecrate yourselves therefore, and be holy; for I am the Lord your God. }{ }^{8} \text { Keep my statutes, and observe them; I } \\
\text { am the Lord; I sanctify you. }\end{array}$ \\
\hline
\end{tabular}

BHS, original Hebrew text; NRSV, New Revised Standard Version.

Code (Otto 1999:172-176). ${ }^{20}$ The frame includes texts such as Leviticus 18:1-5, 24-30; 19:1-4; 20:7-8, 22-27; 22:8, 31-33; $25: 18-19,38,42 a, 55$ and 26:1-2. These texts are sometimes found at the beginning (e.g. Lv 18 and 19) and/or end (Lv 18 or 22) of a chapter and are sometimes found somewhere in the middle. These texts tend to motivate the addressees to keep the commandments and in chapters 18 and 20 they are closely connected to a certain view of the land. The previous inhabitants of the land did certain things wrong and thus lost the land ( $\operatorname{Lv} 18: 25,27,28 ; 20: 22,24)$. The threat is now made to the addressees that non-compliance with these laws will inevitably mean losing the land, as the previous inhabitants had. Thus, the language of holiness is intimately mixed with references to gaining land and the threat of losing land. But to return to our original question: How do Pentateuch scholars explain this change from a narrow cultic focus to a somewhat broader ethical view?

\section{Israel Knohl}

As mentioned above, Israel Knohl is one of those scholars who could be regarded as following in the footsteps of Hezekiel Kaufmann, who responded to Wellhausen's rather negative portrayal of $\mathrm{P}$ by arguing for a pre-exilic dating of $\mathrm{P} .{ }^{21} \mathrm{Knohl}$ is also one of those scholars who argue that $\mathrm{H}$ came after $\mathrm{P}$ and who has clearly shown that the focus of the Holiness School (HS) is more ethical than that of Priestly Torah (PT). Like some of the scholars mentioned above (such as Wright, Bibb etc.), Knohl (1995:180-186) also regards Holiness in HS as much more inclusive than in PT. Holiness is not something which is limited to the sanctuary as in PT, but HS actually believes 'that the holiness of God expands beyond the Sanctuary to encompass the settlements of the entire congregation of Israel, in whose midst God dwells' (Knohl 1995:185). Knohl (1995:175-180) also describes the unique contribution of HS as the combination of cult with morality, which entails a 'systematic effort to integrate

20.See also the discussion by Achenbach (2008:152-155).

21.Knohl talks of the Priestly Torah (PT) and the Holiness School (HS). The latter were the people who produced the Holiness Code and they also added other texts in the first four books of the Pentateuch, which is then often described as HS. See Knoh (1995:104-106) for an overview. the laws of morality and social justice into the religiouscultic corpus'. For him (1995:220), the PT was a document written 'at some time during the two-hundred-year period between the construction of Solomon's Temple and the reign of Ahaz-Hezekiah - between the mid-tenth century B.C.E. and the mid-eight century B.C.E.', whereas HS was active over an even longer time period, running all the way from the Neo-Assyrian period to the Persian period (Knohl 1995:204-212). His explanation for this ethical turn is closely linked to his dating of the activity of the two priestly schools which produced first PT and then later H. Knohl (1995:207-209) dates the starting point of the activity of HS to the time of $\mathrm{Ahaz}^{22}$ and Hezekiah and actually speculates that the reforms instituted by Hezekiah were a result of the activity of the HS. This means a date between 743 BCE and 701 BCE. This is also the time of the classical prophets and Knohl (1995:212-215) specifically mentions prophets such as Amos, Micah ${ }^{23}$ and especially Isaiah. Texts such as Amos 5:25 and Micah 3:9-12 have often been the centre of debates about the tension between the prophets and the cult.. ${ }^{24}$ But for Knohl (1995:213), Isaiah specifically is important, because he also refers to holiness and, like HS, expresses the 'moral dimension' of holiness. The ethical turn in $H$ is thus a response to the critique of the prophets. The following point from Knohl (1995) expresses this well:

On the one hand, HS preserves the centrality of cultic institutions. The Temple, the sacrifices, and the status of the priests are discussed at great length and are accorded a great measure of holiness; likewise, much emphasis is placed on the Sabbath and the festivals. On the other hand, HS assigns great importance to

22.One of Knohl's (1995:206-207) arguments has to do with the mention of Molech worship and Leviticus 18 and 20, which was mentioned in the Former Prophets in the times of both Ahaz and Manasseh. He eventually argues for the earlier period, because we find no mention of the 'acute social polarization that leads to the uprooting of farmers from their lands and their enslavement to the rich' in the time of Manasseh and Josiah. Another reason is the fact that idolatrous worship was widespread in the time of Manasseh, but is not mentioned in $\mathrm{H}$. All of this means that it probably did not originate in the time of Manasseh, but earlier in the time of Ahaz and Hezekiah.

23.See also Jagersma (1972:125), who argues that the 'social justice' texts mentioned above in Leviticus 19 (vv. 13-18) are related to texts from Amos and Micah.

24.For the classic debate about the prophets and the cult, see Barton (2007) Bibb (2004) and Zevit (2004). Zevit also provides an overview of the historical development of this debate. Of these three examples, only Barton argues that the prophets might have been anti-ritualistic. 
the practice of morality and the cult, incorporating both under the broadened rubric of holiness. The call 'You shall be holy, for I am holy' can only be realized through observance of the cultic laws along with practice of just ways of love of the neighbor and the stranger. We thus find a moral refinement of the purely cultic conception, stemming from Priestly circles themselves, under the influence of the prophetic critique. (p. 216)

For Knohl the ethical turn is the result of external critique and 'external' here does not mean outside Israel but outside of priestly circles. Knohl (1995:222-223) further argues that the 8th century was a period of 'political, social, cultural and religious upheavals' in which Israel and Judah witnessed the rise of Assyria, which also meant the demise of the Northern Kingdom. This rather confusing time 'drew the Jerusalem priesthood out of the shelter of the Temple and stimulated forces of renewal and creativity ${ }^{\prime}$ and it is in this historical context that we should look for the creation of the Holiness Code. The attractive part of his proposal is that it provides a plausible historical context which could account for priestly authors extending their traditional focus on the cult by adding social and ethical prescriptions into the mix. His argument also acknowledges the moral content of $\mathrm{H}$ and seeks an historical context for this content. Yet the main problem with Knohl's proposal is actually the very historical context which he indicates. The idea first proposed by Kaufmann that $P$ is pre-exilic has not really caught on in European historicalcritical academic circles and it is still mostly limited to Jewish circles. ${ }^{25}$ But Knohl's argument is different from that of other members of the Kaufmann School, such as Milgrom, for instance, in the sense that Knohl allows for later reworking of sections of Leviticus well into the Persian period. This has led to criticism such as the following from Nihan (2007):

Yet since he assumes simultaneously a pre-exilic dating not only for $\mathrm{P}$, but even for $\mathrm{H}$, he is confronted with a manifest contradiction obliging him to postulate that contrary to the Priestly school the literary activity of the 'Holiness School' (HS) extended over several centuries, from the Neo-Assyrian period down into the Persian era. (p. 563)

I am not sure that Nihan is correct with regard to Knohl's dating of the original PT, but the criticism is valid in the sense that Knohl leaves too many back doors open. The HS was presumably active over a very long a period starting in the 8 th and ending in the 5th century. The problem is that he is trying to say that both Wellhausen and Kaufmann were correct (see Knohl 1995:200-201). This sounds too much like sitting on the historical-critical fence, which is one thing that cannot be said of Eckart Otto's proposal for dating the Holiness Code.

\section{Eckart Otto}

Otto's (2009:135-139) hypothesis of how the Pentateuch was created is much more detailed than that of Knohl and takes us to a totally different time, namely the Persian period. In short, Otto argues that during the exilic period, two important works were written engaging with Israel's identity. The first consisted of a Priestly Code that extended from Genesis 1 to end somewhere in the Sinai pericope. ${ }^{26}$ The second started with Deuteronomy 5 and concluded in Joshua 23. Out of these two works, a Hexateuch was formed in the post-exilic period that extended from Genesis 1 to Joshua 24. Otto dates this Hexateuch to the time of Nehemiah. In the Hexateuch, the land is the most important gift to Israel. Later, the Hexateuch was changed to a Pentateuch by cutting off the Book of Joshua at the time of Ezra; this was done for the sake of Jews living in the diaspora and in response to their quest for identity (Otto 2009):

Israel's identity should not be constituted by living in the Promised Land but by the Torah given at Mount Sinai in the desert outside the Promised Land: Jews should be those all over the world who kept YHWH's Torah, regardless of whether they lived in the Promised Land or the diaspora. ${ }^{27}$ (p. 137)

Thus, initially the Hexateuch was a defining document for Persian Period Judaism in which Jewish identity was closely linked to staying in the Promised Land. With the Book of Joshua added to the Pentateuch, the promise of land in the Book of Genesis (especially chapter 15) is thus fulfilled. Later, under pressure from Jews in the diaspora, this is changed to the Pentateuch. Joshua is cut off and now Jewish identity is linked to living the Torah irrespective of where you are. There is something very attractive about this theory. As Römer (2011) puts it:

the two options betray quite different ideas about what should be cardinal to Judaism: for the Hexateuch the main theme is land, whereas for the Pentateuch Israel's identity is founded in the Torah of Moses. This makes it quite understandable that the idea of a Hexateuch was rejected in favor of the Torah. (p. 31)

Yet for Otto (1999:131), the same people who removed the Book of Joshua also added the Holiness Code to $\mathrm{P}^{28}$ in a process intending to even out or balance ${ }^{29}$ the Priestly document with that of Deuteronomy by extending the Sinai pericope. For Otto (1999:138), texts such as the Covenant Code, Deuteronomy and the Priestly text are 'taken up'30 in the Holiness Code, which, in some cases, corrects these earlier collections. Deuteronomy had already corrected the Covenant Code, but now in the latest collection (i.e. the Holiness Code) earlier legal collections are often modified. An example from Leviticus 19:15, which we already said is described by Nihan (2007:461) as 'social justice', might help (Otto 1999:147-148).

In Otto's understanding, Exodus 23:3, 6 have been corrected in Deuteronomy 16:18-20. In Exodus 23:3, 6, it is clearly stated that in legal practice, on the one hand, one should not be partial towards the poor (v. 3) simply because they are poor, but on the other side, the poor should also get their fair

26.In Otto's (2012:250) commentary on Deuteronomy, he argues that PS (Priestly Supplement) ended in Leviticus 16, whereas an earlier version of $P$ ended in Leviticus 9. But it was the later (PS) version of $P$ which was combined with Deuteronomy* and Joshua* to form the Hexateuch.

27.See also Otto (2012:171-172).

28.For a similar argument see Achenbach (2008:155).

29.0tto (1999:131) uses the noun 'Ausgleich' to describe this process. It is difficult to find an English equivalent, but 'evening out' or 'balancing' or even 'compensation' might do.

30.Otto (1999:138) often uses the German noun 'Rezeption', which describes a process whereby the Holiness Code engages with older codes and reinterprets them. 
share of justice. Deuteronomy 16:18-20 modifies this to be more focused, according to Otto, on the plight of the poor, although it would probably be more accurate to say that the text is critical of the rich, who have the ability to bribe judges. In Leviticus 19:15, things are more balanced again in the sense that it warns against partiality towards the poor and being influenced by the rich and it thus takes the more onesided view found in Deuteronomy 16:18-20 back to the more balanced view of the original Covenant Code.

Otto (1999:150) would further argue that verses 13-18 of Leviticus 19, which were described earlier as being about 'social justice', is simply a case of $\mathrm{H}$ engaging with earlier texts in Deuteronomy such as 24:6-7, 10-22 and 25:1-4. The ethical content in $\mathrm{H}$, for $\mathrm{Otto}$, is the result of inner biblical exegesis, which is a process whereby the authors of the Holiness Code were reinterpreting texts from the Decalogue, the Deuteronomic Code and the Covenant Code. It was part and parcel of the process by which the Pentateuch was created; it is not a response to prophetic critique (as Knohl would have it), but rather part of a broader process of negotiating identity in the post-exilic period. In this process of identity negotiation, post-exilic Judaism chose to link its identity to right living, or to following the Torah not to the Promised Land. This makes Otto's argument very attractive.

\section{Conclusion}

I have already pointed out why I would support Otto's argument rather than Knohl's, simply because I would prefer to follow the majority of scholars who argue that Priestly texts are exilic and post-exilic. I do find Otto's hypothesis on the creation of the Hexateuch and then the Pentateuch fascinating and attractive. The most attractive part of this hypothesis is obviously the construction of an identity which is not dependent on land, but closely connected to a way of living, or, in other words, to a kind of ethics as found in the Holiness Code. Yet there is one major problem with this hypothesis and it has to do with the role played by the Holiness Code in his hypothesis.

If in his understanding Jewish identity moved from 'connected to land' to 'right living', why then is the Holiness Code, which was supposed to be added when the Book of Joshua was cut off, still very much obsessed with land? On three occasions (Leviticus 19:23, 23:10 and 25:2) one finds the clause 'when you come into the land'. Two of the occurrences are in chapters where one finds a lot of ethical material, namely chapters 19 and 25. Furthermore, some scholars ${ }^{31}$ have used these texts to argue that $\mathrm{H}$ is 'programmatic', referring to the programme of the exiles who are about to return to the land. Some scholars have also described the role of land as such in the Holiness Code..$^{32}$ This is one of the main themes in the Holiness Code. If the purpose of changing the Hexateuch to a Pentateuch was to move away from an identity connected to land, why is the Holiness Code so very much still about land?

31.See, for instance, Middlemas (2007:135), who refers to work of Clements. Or a much older example would be Jagersma (1972:128-130), who argues that the exile is the historical context for Leviticus 19 and therefore the texts referring to imminent return.

32.The best example would be Joosten (1996:137-189), who offers two substantial chapters on how land is depicted in the Holiness Code.
It is also very difficult to separate right living in the Holiness Code from land. In the parenetic texts, ${ }^{33}$ land is very much the carrot used to motivate addressees to do these things. Otto (1999:172-176) provides a fascinating description of the parenetic frame which, as we said above, includes the statements about holiness. As Otto (1999) puts it:

Wer den Geboten folgt, werde leben. Die Völker, die ihnen nicht folgen, bringen sich also um ihr Leben - das Land werde sie ausspeien. [Those who follow the commands, will live. The nations who do not follow the commands are killing themselves - the land will spit them out.] (p. 173, [author's own translation])

How would diaspora Judaism respond to this carrot? Is that not why the Book of Joshua was removed in the first instance: to disassociate identity from living in the land and instead build identity around living the Torah? Yet, in these texts in the parenetic frame, right living is so intertwined with living in the land that it is difficult to separate the two.

We thus find ourselves in a position where we have to acknowledge that despite the attractiveness of Otto's Pentateuch-Hexateuch hypothesis, it is not clear what role the Holiness Code played in all of this. It sounds very convincing to argue that the ethical turn in Leviticus is the consequence of a quest for Jewish identity in the Persian Period, but this new ethical identity of the Holiness Code is still very land-sensitive and it is therefore difficult to imagine the creation of the Holiness Code by means of the same creative stroke which severed the book of Joshua from the Hexateuch. The arguments presented by scholars such as Otto (1999) - and now more recently in much more detail by Nihan (2007:616) - that the Holiness Code is a 'systematic reception of other codes in the Pentateuch, the Decalogue, the "Covenant Code" (CC), and the Deuteronomic code (D)' are difficult to dispute and will dominate Pentateuch scholarship for some time to come. It means that the Holiness Code had some role to play in the creation of the Pentateuch. Even Nihan (2007:616-617), who disagrees with Otto that the Holiness Code is the product of the 'pentateuchal redactor', has to acknowledge that 'the composition of this code $[=\mathrm{H}]$ should be related to the first edition of the Pentateuch'.

It would thus seem that land and identity cannot be so readily divorced as alleged in Otto's hypothesis. Furthermore, one cannot really talk of ritual and ethics in Leviticus without venturing into debates on identity and land. Identity in the second half of Leviticus is thus very much intertwined with the cult and its rituals, but also connected to a community striving to be holy, but then a community closely connected to the land promised in the Holiness Code.

\section{Acknowledgements Competing interests}

The author declares that he has no financial or personal relationships that may have inappropriately influenced him in writing this article.

33.Leviticus 18:1-5, 24-30; 19:1-4; 20:7-8, 22-27; 22:8, 31-33; 15:18-19, 38, $42 a$ $55 ; 26: 1-2$. 


\section{References}

Achenbach, R., 2008, 'Das Heiligkeitzgesetz und die sakralen Ordnungen des Numeribuches im Horizont der Pentateuchredaktion', in T. Römer (ed.), The Books of Leviticus and Numbers, pp. 145-176, Uitgeverij Peeters, Leuven. (Bibliotheca Ephemeridum Theologicarum Lovaniensium).

Balentine, S.E., 1999, The Torah's vision of worship, Fortress Press, Minneapolis. (Overtures to Biblical Theology).

Barton, J., 2007, 'The prophets and the cult', in J. Day (ed.), Temple and worship in biblical Israel. Proceedings of the Oxford Old Testament Seminar, pp. 111-122, T\&T Clark, London. (Library of Hebrew Bible/Old Testament Studies).

Bell, C., 1992, Ritual theory, ritual practice, Oxford University Press, Oxford.

Bibb, B.D., 2004, 'The prophetic critique of ritual in Old Testament theology', in L.L. Grabbe \& A.O. Bellis (eds.), The priests in the prophets. The portrayal of priests, prophets and other religious specialists in the latter prophets, pp. 31-43, T\&T Clark, London.

Bibb, B.D., 2009, Ritual words and narrative worlds in the Book of Leviticus, T\&T Clark London. (Library of Hebrew Bible/Old Testament Studies).

Blenkinsopp, J., 1996, 'An assessment of the alleged pre-exilic date of the Priestly material in the Pentateuch', Zeitschrift für die Alttestamentliche Wissenschaft 108, 495-518. http://dx.doi.org/10.1515/zatw.1996.108.4.495

Collins, J.J., 2004, Introduction to the Hebrew Bible, Fortress Press, Minneapolis.

Grünwaldt, K., 1999, Das Heiligkeitsgesetz Leviticus 17-26. Urspüngliche Gestalt, Tradition und Theologie, De Gruyter, Berlin. (Beihefte zur Zeitschrift für die alttestamentliche Wissenschaft).

Jagersma, H., 1972, Leviticus 19. Identiteit - Bevrijding - Gemeenschap, Van Gorcum \& Comp. N.V., Assen.

Joosten, J., 1996, People and land in the Holiness Code. An exegetical study of the ideational framework of the law in Leviticus 17-26, Brill, Leiden. (Supplements to Vetus Testamentum)

Joüon, P. \& Muraoka, T., 2006, A grammar of biblical Hebrew: Revised English edition, Editrice Pontificio Instituto Biblico, Rome. (Subsidia Biblica).

Jüngling, H.-W., 1999, 'Das Buch Leviticus in der Forschung seit Karl Elliger's Kommentar aus dem Jahr 1966', in H.-J. Fabry \& H.-W. Jüngling (eds.), Levitikus als Buch, pp. 1-45, Philo, Bonn. (Bonner Biblische Beiträge).

Knohl, I., 1995, The Sanctuary of Silence. The Priestly Torah and the Holiness School, Fortress Press, Minneapolis.

Krapf, T.M., 1992, Die Priesterschrift und die vorexilische Zeit. Yehezkel Kaufmanns vernachlässigter Beitrag zur Geschichte der biblischen Religion, Vandenhoeck \& Ruprecht, Göttingen.

Mathys, H.-P., 1986, Liebe deinen Nächsten wie dich selbst. Untersuchungen zum alttestamentliche Gebod der Nächstenliebe (Lev 19, 18), Vandenhoeck \& Ruprecht, Göttingen. (Orbis biblicus et orientalis).
Meyer, E.E., 2010, 'Dating the Priestly text in the pre-exilic period: Some remarks about anachronistic slips and other obstacles', Verbum et Ecclesia 31(1), Art. \#423, 6 pages. $\mathrm{http}: / / \mathrm{dx}$.doi.org/10.4102/ve.v31i1.423

Meyer, E.E., 2012, 'Leviticus 17 as a bridge between P and H, with a twist of D?', Journal for Semitics 21(1), 106-124.

Middlemas, J., 2007, The Templeless age: An introduction to the history, literature, and theology of the 'Exile', Westminster John Knox, Louisville.

Milgrom, J., 1991, Leviticus 1-16. A new translation with introduction and commentary, Doubleday, New York. (Anchor Bible).

Milgrom, J., 1999, 'The antiquity of the Priestly source: A reply to Joseph Blenkinsopp', Zeitschrift für die Alttestamentliche Wissenschaft 111, 10-22. http://dx.doi. org/10.1515/zatw.1999.111.1.10

Milgrom, J., 2004, Leviticus. A book of ritual and ethics. A continental commentary, Fortress Press, Minneapolis.

Nihan, C., 2007, From Priestly Torah to Pentateuch, Mohr Siebeck, Tübingen. (Forschungen zum Alten Testament. 2. Reihe).

Otto, E., 1999, 'Innerbiblische Exegese im Heiligkeitsgesetz Levitikus 17-26', in H. J. Fabry \& H.-W. Jüngling (eds.), Levitikus als Buch, pp. 125-196, Philo, Bonn. (Bonner Biblische Beiträge).

Otto, E., 2009, 'The Holiness Code in diachrony and synchrony in the lega hermeneutics of the Pentateuch', in S. Schectman \& J.S. Baden (eds), The strato of the Priestly writings. Contemporary debate and future directions, pp. 135-156, Theologischer Verlag Zürich, Zürich. (Abhandlungen zur Theologie des Alten und Neuen Testaments).

Otto, E., 2012, Deuteronomium 1-11. Erster Teilband: 1,1-4, 43, Herder, Freiburg.

Römer, T., 2011, 'How many books (teuchs): Pentateuch, Hexateuch, Deuteronomistic History, or Enneateuch?', in T.B. Dozeman, T. Römer \& K. Schmid (eds.), Pentateuch, Hexateuch, or Enneateuch? Identifying literary works in Genesis through Kings, pp. 25-42, Society of Biblical Literature, Atlanta. PMid:21054202

Stackert, J., 2009, 'The Holiness legislation and its Pentateuchal sources: Revision, supplementation, and replacement', in S. Schectman \& J.S. Baden (eds.), The strata of the Priestly writings. Contemporary debate and future directions, $\mathrm{pp}$ 187-201, Theologischer Verlag Zürich, Zürich. (Abhandlungen zur Theologie des Alten und Neuen Testaments).

Trevaskis, L.M., 2011, Holiness, ethics and ritual in Leviticus, Sheffield Phoenix Press, Sheffield. (Hebrew Bible Monographs).

Wright, D.P., 1999, 'Holiness in Leviticus and beyond. Differing perspectives', Interpretation 53, 351-364. http://dx.doi.org/10.1177/002096439905300404

Wright, D.P., 2001, Ritual in narrative: The dynamics of feasting, mourning, and retaliation rites in the Ugaritic Tale of Aqhat, Eisenbrauns, Winona Lake.

Zevit, Z., 2004, 'The prophet versus priest antagonism hypothesis: Its history and origin', in L.L. Grabbe \& A.O. Bellis (eds.), The priests in the prophets. The portrayal of priests, prophets and other religious specialists in the latter prophets, pp. 189217, T\&T Clark, London. (Library of Hebrew Bible/Old Testament Studies). 